\title{
Nursing practice in home care: the mediation of care by reflexivity
}

\author{
Prática da enfermeira na atenção domiciliar: o cuidado mediado pela reflexividade \\ La práctica de enfermería en la atención a domicilio: la mediación del cuidado por la reflexividad
}

Angélica Mônica Andrade'
ORCID: 0000-0003-2684-1134

Edna Aparecida Barbosa de Castro"

ORCID: 0000-0001-9555-1996

Maria José Menezes Brito'

ORCID: 0000-0001-9183-1982

Patrícia Pinto Braga "'

ORCID: 0000-0002-1756-9186

Kênia Lara Silva'

ORCID: 0000-0003-3924-2122

'Universidade Federal de Minas Gerais.

Belo Horizonte, Minas Gerais, Brazil.

"Universidade Federal de Juiz de Fora.

Juiz de Fora, Minas Gerais, Brazil.

I" Universidade Federal de São João Del-Rei. Divinópolis, Minas Gerais, Brazil.

How to cite this article: Andrade AM, Castro EAB, Brito MJM, Braga PP, Silva KL. Nursing practice in home care: the mediation of care by reflexivity Rev Bras Enferm. 2019;72(4):956-63. doi: http://dx.doi.org/10.1590/0034-7167-2018-0431

\section{Corresponding Author:}

Kênia Lara Silva

E-mail: kenialara17@gmail.com

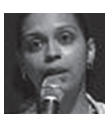

Submission: 06-08-2018

Approval: 09-09-2018

\section{ABSTRACT}

Objective: To analyze the practice of nurses in home care, considering the mediation of care by reflexivity. Method: Unique, qualitative case study, anchored in the dialectical framework. The participants were 13 nurses who work in home care in Minas Gerais. Data were obtained by participant observation and interview, and submitted to critical discourse analysis. Results: Nursing care at home involves the repetitions of everyday actions and a degree of unpredictability. Reflexivity, according to Schön's theoretical framework, emerges as a component of professional practice that leads to the practice of care as a continuous assessment of work, and also to reflection on the challenges imposed by conflicting situations. Reflexivity also stems from professionals' search for improvements in their practices. Final considerations: We identified the presence of actions and knowledge mobilized by the reflexivity of the nurse in the home care setting. The following were the elements of this reflexive practice: knowing-in-action, reflection-in-action and reflection reflection-in-action.

Descriptors: Nursing Care; Nurse's Role; Nursing; Learning; Home Care Services.

\section{RESUMO}

Objetivo: Analisar a prática de enfermeiras na atenção domiciliar, considerando a realização do cuidado mediado pela reflexividade. Método: Estudo de caso único, qualitativo, ancorado no referencial dialético. Participaram 13 enfermeiras que atuam na atenção domiciliar em Minas Gerais. Os dados foram obtidos por observação participante e entrevista e submetidos à análise de discurso crítica. Resultados: $O$ cuidado da enfermeira no domicílio é composto por repetições de ações cotidianas e pela imprevisibilidade. A reflexividade, segundo referencial teórico de Schön, emerge como um componente da prática profissional que leva à realização do cuidado em uma avaliação contínua do trabalho e da reflexão acerca dos desafios diante de situações conflitantes e da busca de melhoria em suas práticas. Considerações finais: Identificou-se a presença de fazeres e saberes mobilizados pela reflexividade da enfermeira no domicílio, e os seguintes elementos de uma prática reflexiva: o conhecer-na-ação, a reflexão-na-ação e a reflexão sobre este último. Descritores: Cuidados de Enfermagem; Papel do Profissional de Enfermagem; Enfermagem; Aprendizagem; Serviços de Assistência Domiciliar.

\section{RESUMEN}

Objetivo: Analizar la práctica de enfermería en la atención a domicilio, desde la mediación del cuidado por la reflexividad. Método: Estudio de caso único, cualitativo, en base de la dialéctica referencial. Han participado 13 enfermeras que trabajan en la atención domiciliaria en Minas Gerais, Brasil. En la recolección de datos se utilizó la observación participante y las entrevistas, pasando a un análisis crítico del discurso. Resultados: El cuidado de enfermería a domicilio consiste en repeticiones de acciones cotidianas e imprevisibilidad. La reflexividad, desde el marco teórico de Schön, emerge como un componente de la práctica profesional que conduce al logro del cuidado en una evaluación continua del trabajo y la reflexión sobre los desafíos que enfrentan con situaciones conflictivas y la búsqueda de la mejora en sus prácticas. Consideraciones finales: Se identificaron la presencia de quehaceres y saberes influidos por la reflexividad en la enfermería a domicilio, y los siguientes elementos de la práctica reflexiva: el conocimiento-en-la-acción, la reflexión-en-la-acción y su reflexión. Descriptores: Atención de Enfermería; Desafío del Profesional de Enfermería; Enfermería; Aprendizaje; Servicios de Atención de Salud a Domicilio. 


\section{INTRODUCTION}

Considering its ability to increase life expectancy, home care $(\mathrm{HC})$ is an important modality of health care. It is associated with the increase of chronic-degenerative diseases that do not necessarily require hospitalization, but which do require assistance ${ }^{(1)}$. In addition, the relevance of home care is linked to the introduction of new relationships that increase access, autonomy and quality of life for the user, providing comfort in the home, bonding with the family and the home care staff, and overcoming barriers in access to other points of the health care network ${ }^{(2)}$.

In $\mathrm{HC}$, the centrality of nurses is seen in their role as managers of care and assistance, in the health education they provide to users, family and caregivers, and in their activities toward permanent education and knowledge production. This occurs through the adoption, application and transformation of knowledge produced by the nursing science, contributing to the emergence of new research objects ${ }^{(3-5)}$. The nursing professional has an indispensable role in the home care modality. This role is expressed through the coordination of the home care plan, the bonds established with the users and their families, the effective articulation between the family and the multiprofessional team, the training of the family caregiver, the supervision of the nursing technician, and also the identification of demands for other professionals ${ }^{(3-6)}$.

Regardless of its potentiality, HC poses challenges to health workers, considering the need to understand the uniqueness of the space in which they work, which encompasses the economic, social and emotional aspects of the user and his/her family; available resources; social support network; hygiene and safety of the house; as well as the entire environment around the patient and the patient's family ${ }^{(1,7)}$. In the context of training, studies indicate that nurses are not prepared to deal with $\mathrm{HC}^{\prime}$ 's particularities ${ }^{(3,8-10)}$. Even when they have it, academic formation related to $\mathrm{HC}$ tends to be punctual in face of the complexity of practicing domestic care ${ }^{(8-10)}$.

The knowledge used in home care also comes from formal education, but it is mainly from experience, since $\mathrm{HC}$ involves learning how to act according to the requirements of situations that are often unpredictable ${ }^{(5-6)}$. Thus, nurses' competences begin to be developed during training and continue to develop in their daily $\mathrm{HC}$ practice, through reflective learning ${ }^{(11)}$. This learning practice, according to Donald Schön's theoretical referential, refers to the activity in which individuals reflects in the action and on the action, using experience as a means of continuously improving their performance ${ }^{(12)}$.

Schön's theory addresses the need for professionals to reflect on their own practice, based on the assumption that reflection is an instrument in the development of thought and action. In this conception, professionals experience their own actions and evaluate them in terms of a dialectical relationship, in which they try to perceive and understand their own way of thinking and acting, seeking advances and achievements in their work. The development of a reflexive practice for the formation of a professional focuses on three levels: "knowing-in-action," "reflection-in-action," and "reflection on reflection-in-action". Knowing-in-action represents the pre-acquired knowledge, values, perceptions, and concepts that accompany professionals in their daily lives. Reflection-inaction provides critical thinking about unpredictable situations, allowing professionals to reorganize strategies of action, as well as understand phenomena and ways of conceiving problems ${ }^{(12)}$. The reflection on reflection-in-action comes into play when the contemplation of the previously carried out reflection-in-action enables professionals to analyze their thinking and doing, through which they can become even more skillful ${ }^{(12)}$.

\section{OBJECTIVE}

Objective: To analyze the practice of nurses in home care, considering the practice of care mediated by reflexivity.

\section{METHODS}

\section{Ethical aspects}

This research project was approved by the Human Research Ethics Committee of the Federal University of Minas Gerais and all stages were carried out in accordance with National Health Council Resolution 466/2012(13).

\section{Theoretical and methodological background}

A single case study based on the theoretical-methodological framework of dialectics ${ }^{(14-16)}$, dealing with"nurses' performance in high complexity home care," considering that the greater the complexity of $\mathrm{HC}$ care, the more reflexivity is required in the practice of nurses ${ }^{(11)}$.

\section{Type of study}

A descriptive and interpretive study, using the qualitative approach $^{(14)}$.

\section{Scenario of the study}

The scenario consisted of two municipalities in Minas Gerais, with initials $U$ and $B$, selected among 22 municipalities that had Home Care Services (SAD) linked to the state's Better At Home (Melhor em Casa) program. The selection criteria of the municipalities were the number of nurses working in $\mathrm{HC}$ and the indication of performing invasive and/or non-invasive mechanical ventilation by the SAD.

\section{Data source}

The research participants were nurses working with $\mathrm{HC}$ teams in the chosen scenarios: twelve women and one man. In order to preserve participants' identities, the female gender was used as a standard when referring to them. A total of 13 nurses participated in the study.

\section{Data collection and organization}

Data production occurred from May to December 2016, in two stages. The first was the peripheral participant observation of the nurses' practice, guided by a script and with data recording using a field diary and audio(17). The observation was guided by the description of the following aspects: subjects present, actions performed by the nurse, instruments and technologies used in 
their practice, challenging situations, and researcher's perception of situations. The researcher's entrance into the homes was authorized by the professionals who conducted the care practices and by the users or the ones responsible for them.

Observations took place during nurses' home care work, comprised of: palliative care visits, death and post-death, discharge, admissions, medication administration, complex dressing, care with oxygen therapy and mechanical ventilation (including pediatric), paracentesis, evaluation, and intercurrent care. There were 272 visits to 186 patients, totaling 266 hours and 30 minutes of observation, whose interruption criterion was the fulfillment of the research objective. The elaborated field diary resulted in 277 pages of text, coded as: "Field Diary - Participant - Venue and visit number."

Guided interviews were also conducted through a semi-structured script ${ }^{(16)}$, whose questions were:"Describe situations that required learning during the time you have been active in $\mathrm{HC}^{\prime}$ and "Among these, how did you handle situations of uncertainty, complexity or for which you were not prepared?" (Auxiliary questions:"During your daily work, do you usually reflect on your actions?"'In what situations are these reflections developed?"“"In what situations do you stop reflecting?"). Interviews with the 13 nurses included audio recording and field notes with researcher impressions ${ }^{(16)}$, after the observational component of each scenario was complete. These were individually scheduled and performed, amounting to a total of 8 hours and 58 minutes of recording time and 169 pages of text, with the transcript following the conventions, models and guidelines proposed for the area ${ }^{(18-19)}$. Participants received an identification assigned by an alphanumeric classification composed by the initial letter of the municipality $(U$ or B), and a randomly-assigned number between 01 to 09 for $\mathrm{U}$, and 01 to 04 for $B$. The production of the data guaranteed the qualitative research criteria: credibility, portability and confirmability ${ }^{(20)}$.

\section{Data analysis}

Analysis was carried out by the interpretation of the category of reflexive learning, anchored in the theoretical referential of Donald Schön ${ }^{(12)}$. The empirical data were submitted to Critical Discourse Analysis (CDA) ${ }^{(21)}$, considering the dimensions of text, discourse practice and social practice in socio-historical and social-transformation contexts ${ }^{(21)}$.

The presentation of the results followed the recommendations for reports of qualitative research projects using interviews, available in the Consolidated criteria for reporting qualitative research (COREQ) ${ }^{(22)}$.

\section{RESULTS}

The relevance of the role of the nurse in several actions, involving assistance, education and management, was identified. Such actions are directed towards care for users, family and caregivers, as well as the management of care and service.

First visit to the patient suffering from osteomyelitis. [...] [The nurse] performs the care visit on the porch of the house. [...] evaluates the wound. Organizes the material on the porch's protective fence. [...] Uses phytotherapic coverings. [...] protects sharp materials using an inox case wrapped by the medical gloves used in the procedure. (Field Diary V215-B04)
In the car, the nurse had said it was a very difficult, very large bandage. [...] She applies the dressing to one leg, and the nursing technician applies it to the other. The nurse crouches to perform the dressing. (Field Diary V47-U07)

In the living room, she tells me that she gives directions to the nursing technicians, because they often make the visits alone, especially on weekends. She said she's trying to bring improvements to the service. (Field Diary Headquarters-B02)

The caregiver asks about oral hygiene [...]. The nurse reports that she will ask for the dentist to visit. [...] The caregiver also asks about the use of nutritional supplements [...]. The nurse mentions that she will request a visit from the nutritionist. (Field Diary V03-U02)

The patient was in the shower. The nurse waited and talked to the daughter about maintenance of the fan's circuit. [...] In the car, the nurse mentions that "for ventilation at home, the family has to receive guidance." (Field Diary V222-B04)

During home visits, nurses establish ties with patients and families, especially in prolonged care, such as palliative care and patients with complex wounds.

[After performing the dressing and finishing the patient visit] The nurse goes to the kitchen to have coffee and talks to the patient's daughter about care. [...] In the car, the nurse says that it is important to stop and talk to the daughter, since this makes the family feel welcome. [...]. According to her, this is important for building a bond and a relationship of trust with the family. (Diário de Campo V97-U06)

Upon arriving at the house, U02 knocks at the gate and the patient's daughter greets us with tears in her eyes, hugs the nurse and says, "she's going." We go in and, arriving at the door of the room where the patient was, the nurse notices that the patient had just passed away. [...] She approaches slowly and gives her support to the daughter. [...] She hugs the family members and also weeps [...] She helps the daughter remove the blankets and fold them, in a respectful silence, often with her head down. [...] When we arrived at the SAD headquarters, U02 told me: "No way it gets more intense than that." (Field Diary V10-U02)

The nurse measures the patient's pressure and directs the daughters not to "repeat [the measurement] all the time." The nurse talks to the patient's daughters and says "he is not feeling pain, his breathing is slower, but it's not like it's bad, it is just like a candle burning and extinguishing itself. He is going with serenity on his face, without agony, [...]. Delivery, detachment is the most beautiful form of love. You are delivering him to whomever delivered him to you." The daughter, crying, says "what a beautiful thing." The nurse gives advice on the procedures in case of death: "I'll leave my phone and you can call me directly" and also advises them to call the funeral home if it's dawn, so the following day the doctor can come to testify to the death. (Field Diary V83-U05)

The observation of the nurse's work made it possible to identify the manifestation of a pause in the action, accompanied by silence, as a moment that mobilizes reflection.

The nurse puts gloves on for the procedure and evaluates the wound bed. [...] She is pensive, in silence, looking at the wound, changing her facial expression. (Field Diary V36-U01) 
The physician evaluated the gastrostomy and found extravasation of fluid. She calls the nurse to assess it [...], and the nurse indicates the same procedure used in another case: "fix it with the 'ballerina' technique, just as [YYY]." The nurse pauses to observe and, after a few moments of silent thinking, says that she believes that solution wouldn't actually be helpful. (Diário de Campo V76-U06)

The nurse asks for help from the family to hold the patient's arm. Explains that the patient will feel "two slight pinches, since there are two different tests." [...] To determine if two punctures have to be performed, the nurse seems to be thinking about what she is going to do. She says, in a low voice, "Idon't know. I think I'll have to make two" and pauses in silence, looking at the suitcase with the equipment. "I'II try just one," pauses, and then says: "We'll see." (Field Diary V82-U03)

In all cases, the silent pause indicates a reflection for decision-making. The presence of the metaphor"Itwas as if the rug had been pulled out from underme" present in the speech of $\mathrm{U} 01$ below, indicates the difficulty in explaining to the patient that he had a terminal illness, that is, the difficulty in communicating processes of death and dying. The sense of being "without ground" acted as a mediation for reflection during the visit. Thus, the metaphor was used to highlight the experienced difficulty, associated with a moment of silence.

The nurse reports that the next visit will be to a patient with rectal adenocarcinoma and pulmonarymetastasis [...]. The patient's admission was for palliative care. [...] She asks if the professionals who sent her explained what the "Better At Home" program is like. The patient and the patient's son both answered no. The nurse raised her eyebrows and sat in silence for about five seconds. She asked again and got the same answer. The nurse then explains palliative care, demonstrating difficulty in doing so: her expression shows concern, she speaks very slowly and in a low tone, interspersing speech and moments of silence [...] In the car, the nurse says, "What, how could the oncologist have failed to explain this? How can you fail to explain that the patient has no cure?! How do you fail to explain that the patient is going to die?" Thenurse then summarizes, "I felt like the rug had been pulled out from under me and I didn't know what to do next." (Field Diary V134-U01)

The nurses carry out experiments in which the elaboration of solutions and their execution are supported by a continuous evaluation of their practices, highlighted by the use of evaluative affirmations in the speeches ("if it works," "it may not work," "it is difficult to solve," "if it works, great, if not l'll just change it,"' then we keep trying, to see what's actually going to work").

If the way your colleague told you to do it works, it's at the very least a contribution to you, right? You learned how to work that way, using that procedure; so it's a win-win for everyone, right? And it may also not be an effective way of doing it, right? [...] So I'm not going to do it this way anymore, right? So, everything is a learning process. (Interview U02)

If you're at the patient's home and there's a problem, and the problem is difficult to solve, and when, as sometimes happens, you are able to solve it, you carry this experience forward to the rest of the staff, to your life, to your home, to your relationship. This is the cool part. [...] Or let me give you another example: you think to yourself, "I'll do it like that". Soyou put that way of doing it into practice. If it works, great! Otherwise you'lljust changeit. And so, this is how itworks:you just keep trying. You keep trying untilyou find a way that actually works out. (Interview U06)
The discourses regarding the effectiveness of nurses' practices reveal that reflection is important for the replication of successful actions in similar cases, and also for the reformulation of future actions. It is worth noting that situations of care - such as moments when guidance is given to a caregiver who is seeking a solution - raise a reflection in the work and for the work, as shown by discourse sections U02, U03, and U04 below. We emphasize that the discursive fragments are full of question marks, in statements such as "did I do it right?," "is this really how you do it?" "is there nothing else I can do?," "can this be right?," "what else can I try?" Questions followed by statements refer to the epistemic modality present in the discourse, indicating a commitment to the truth or, in this case, to reflecting in search for answers to the uncertainty that permeates the work.

Sometimes you rethink a guidance you've provided, a point you've made, I... I'm too much like that, I think, and I think a lot, both during [the visit] and after we leave. I have a husband who listens to everything, who tells my stories to other people: sometimes he gives me his opinion, another perspective, and then I say: "Wow, I had not thought about that." Because you are always retracing your steps and asking yourself: did I do it right? (Interview U02)

I reflect so hard, so I can work with other patients, because it's kind of like that, there's always a patient who comes back to or enters your care in a similar condition to someone you've had as a patient before. So every time you have a positive experience, you can apply it to the same situation with another patient [...] I think you have to go for the whole deal, cause the next time you'll have more tranquility, more security to assess if it's worked, or if it'll eventually work. If it does not work, it won't be because you've failed to act, it will be because something made it different. (Interview U03)

I spend all my time asking myself, "Is that really it? Is there nothing else I can do? Really?" Sometimes we exchange experiences, right, and you know, there was this lady ... we talked to several [colleagues] who were taking care of different cases, about her mental disorder. We always ask ourselves, "We're doing this, but what else can I try?" Because I think the most important thing in our profession is to know that you are doing your best for the patient's quality of life, cause if you are not, there is no reason why you should be in this job. And you will only know if you are doing your best when you reflect on it. And then you'll think, "No, I think I can improve this or that, shall we try that?" So we have to reflect every day, in each different situation we face. Personally, I'm always thinking. Even when I'm back home, I'm like, "Oh my God, what am I going to do to fix the [...]? What can I try?" And so we keep searching (Interview U04)

Nevertheless, doubts about the handling of unclear cases marked by the unpredictability of the home care space - manifest themselves throughout nurses' daily practices.

The nurse talks to me about applying the mesh and ponders that it should be the last step. She pauses to think about it and says there is no point in applying it first. In another patient visit [Visit 60], the caregiver asks for the mesh to be applied before the bandage. The nurse sends a message to the nurses' WhatsApp group to ask what her colleagues think. And then she tells the nursing technician to place the mesh last, "since the point of the mesh is to be placed last." (Field Diary V62-U02) 
Sometimes a patient, or a difficulty you are having with a patient, may be very similar to another. Sometimes you try to bring a certain solution to another patient. This almost never works out, because they are different people, people with different realities, right? But... this does make you think... the patient makes you question yourself. Sometimes you have a problem at the patient's home and then you begin to wonder if the other patients are having the same problem, and you begin to question whether YOU are the problem, whether you are doing something wrong. So, it kind of makes you stop and think, right? And then you tell yourself: I'm having this specific nursing care problem, with that specific patient, no? So, I'm going to look at every other patient to check if I'm having the same problem there too, to see whether this is happening only with this one patient, 'cause it may be that I'm doing something wrong, and I may not even know about it. So, a single patient leads to this reflection for me, right? And for all the others, it makes me stop to think, am I doing it right, is this issue happening only with this one patient, or with everyone else too? It makes you broaden your view, observe the rest of the patients to see if it's also so with them, talk to the other nurses to see if the problem is on your side, or specific to that patient. It's a cool moment, to be able... it makes us question a lot. (Interview U06)

The discourses indicate that dealing with patients and caregivers who do not replicate the care expected by the staff is a situation that favors reflexivity. In the $\mathrm{U} 06$ report below, two difficult-to-manage situations are identified, concerning the development of care by the family members and by the patient herself. The interrogative discursive mode indicates a reflexive process of mental elaboration about situations the professional regards as problematic. In addition, the use of discursive metaphors represents action in the face of a conflicting, challenging situation ("you are left with your hands tied"), which produces changes in the way of acting mediated by reflection.

But as I always say, "Have I allowed anything to go unnoticed, have I allowed things to come to this point?", "Let God watch for me, I do not have to do anything, God will take care of me" [referring to something the patient said]. So I saw her there, just like last week, and thought to myself: "wow, has something happened that I've failed to notice, how can this be?" [...] And in my view, the situation is more complex and difficult... we talk a lot about how there aren't enough caregivers. [...] But in my opinion the hardest thing is when you do have [...] a caregiver present, but the patient is still languishing, without proper care [...]. So, your hands are tied. You think, "ah, what now then?" [...] Damn, one time I got really angry at his house, argued with everybody, said that they didn't give a damn for the patient, that I was going to call social services. Until I found out that the father used to drink too much, to beat the mother and his daughters a lot, and that he had raped two of his daughters, who didn't want to be anywhere near his room. To me this was the most impactful case ever. So I thought to myself: "guys, now how the hell can I tell them they have to keep taking care of this person?" [...] Has this situation contributed to any change? Yes, it's contributed a lot. From them on I stopped being angry when I was at patients' houses. We get so focused on things like "oh, the patient is filthy, he is not eating and is not taking showers, so give him a bath, give him food etc." and end up forgetting to ask: what's actually behind it? (Interview U06)

Discursive resources present in the research data - such as silence during observation, evaluative affirmations, or epistemic modality through the use of interrogative phrases and metaphors - indicate the reflexivity characteristic of nurses' home care practices. This reflexivity amounts to a process of mental elaboration, based on daily professional experiences and representations that emerge from conflictive situations.

\section{DISCUSSION}

The findings of this study show a pattern of daily actions and singularities in nurses' $\mathrm{HC}$ practices, derived from the unpredictability of the home care setting. Care, educational and managerial actions by nurses reveal patterns of professional practice during dressing and drug administration, for instance. As such, the findings point to a set of practices that are integral to knowing-in-action.

According to Schön,"the process of knowing-in-action of a professional has its roots in the socially and institutionally structured context shared by a community of professionals" (own translation $^{(12)}$. Acts of knowing-in-action are manifested in the repetition of activities, which imprints to each service its logic of organization, and also the profession's characteristic features. This was observed in the sequence of actions performed during home visits, such as the questioning of patient conditions, venipuncture techniques, complex dressing and medication administration, as well as the provision of guidance for users and caregivers and the supervision of nursing technicians. The scenes observed in this study can be described in terms of strategies, understanding of phenomena and ways of conceiving a task or problem that are appropriate to the situation, and accompany the knowing-in-action of the nurses in their day to day. This knowing is implicit, "tacit" - that is, it cannot always be understood from a verbal description ${ }^{(12)}$. Thus, it is obtained in doing and in relationships with other people.

The act of knowing-in-action allows the professional to be apt in performing his/her tasks. This ability on the part of the nurses was skillfully shown, with responses adjusted to the variations presented by phenomena. The purposeful use of the term "variation," rather than "surprise", has to be emphasized, since changes in context and response did not go beyond the boundaries of the family. We emphasize that the place of development of nursing home care activities, the home, produces variations that require knowing-inpractice, sometimes evading the reproduction of standards. There are scenes in which these variations were predominant: to sit and have a cup of coffee with the family in order to listen to them in a different context, wait for the end of a bath before performing the visit, sharing the same space, offering care alongside different professionals and family members, and to crouch in order to perform the bandage. As such, knowing-in-action is the primary process in the development of a reflective professional ${ }^{(12)}$.

The findings indicate that a pause in action, followed by silence, provokes the reflexivity of the professional. In this sense, reflection can take place "in the midst of action, without interrupting it," that is, in the present-of-action, when "one can still interfere in the developing situation." In this case, thinking serves to reshape what is being done, while the professional is still doing it. This process is called reflection-in-action ${ }^{(12)}$, and may occur through the act of thinking about what is being done, in order to discover how knowing-in-action may have contributed to an unexpected result. Thus, this reflection may reveal itself through a pause 
during action, to do what Hanna Arendt ${ }^{(12)}$ has termed to "stop and think." Lack of thought is a common experience in everyday life, since people hardly have the time, much less the desire to stop and think ${ }^{(23)}$. All thinking is a rethinking, since thought alludes to memory ${ }^{(23)}$. Thinking demands "stop-and-think," without which it is not possible to seek the meanings shown by reflection ${ }^{(24)}$. It should be noted that "in a practical context, as Arendt points out, the activity of thinking will always be present when we have to make new decisions that are provoked by moments of difficulty" (own translation) $)^{(25)}$.

In the process of reflection-in-action, there is a sequence of interrelated "moments," not always clearly distinguished (12), which forms the transition between the act of knowing-in-action and the emergence of routine responses producing something unexpected (a surprise that does not fit into the elements of knowing-in-action). The surprise stands out, drawing attention. Surprise then leads to reflection within the present-of-action. At that moment, reflection is conscious, even if not transmitted through words. Reflection-in-action has a critical function and triggers uncertainty regarding the structure of assumptions underlying the act of knowing-in-action and, thus, the search for new ways of doing. Reflection leads to immediate experiments which can actually work, resulting in what was intended, or producing new surprises that require further reflection and experimentation. Regardless of the order of these moments, what defines reflection-in-action and distinguishes it from other forms of reflection "is its immediate significance for action"(12).

In this respect, in V36-U01, V76-U06, V82-U03 and V134-U01 we noted a similarity between knowing-in-action and reflectionin-action in terms of the sequence of moments. The application of a dressing, evaluation of a gastrostomy, the puncture for blood collection, or the admission of a patient to palliative care are routine actions, observed in the nurse's role in HC. However, in each of them, some specific situation caught the attention of the nurse and raised the need to stop and think, to identify what conditioned this variation and caused the surprise. Thus, for example, during the evaluation of the gastrostomy, it is common for the nurse to evaluate the aspect of the site for insertion of the probe and infusion of the food, which requires knowing-in-action. However, during the action, the nurse identified something out of normality, a dilation of the orifice accompanied by extravasation of gastric contents, which, in turn, had injured the patient's skin. At this moment, faced with an extraneous situation, the nurse consciously seeks solutions that will be tried and tested in action, or during the action. This scene of gastrostomy evaluation exemplifies reflection-in-action.

During an immediate experiment, the product of reflectionin-action, the mobilization of solutions and the act of doing are sustained by a continuous evaluation of the work, highlighted by the use of conditional statements in the nurse's discourse ("if it works", "it may not work," "it's hard to solve," "if it works, great, if not I'll just change it" and "we keep trying, to see what's going to work"). Reflection-in-action, in these cases, allows one to evaluate what has worked in the experiment and the possible need for changes, in search of improvements for the patient.

The search for solutions to problematic situations can be described as a "process of trial and error"(12). It is noteworthy that, during action, the nurse idealizes procedures to solve a problem, uncovers unpleasant surprises and creates corrections. Attempts to solve a problem are not randomly interconnected. The reflection on each attempt and its results creates conditions for the subsequent action. Thus, solutions can be learned through reflexive practice, which in addition provides for the reproduction of the action in future situations. The reflectionin-action is made continuous in the nurses' HC work. Thus, it is a relevant professional advantage in which the abstraction of knowledge through experimentation opens the possibility for correcting failures or searching for improvements throughout the experienced process, establishing a new pattern of conduct ${ }^{(26)}$. In this type of reflection, the action's immediate significance may affect not only future, but also present practices, enabling its reproduction in similar cases to come.

In this context, the discourses also show a reflection on reflection-in-action ("I think a lot, both during [the visit] and after we leave [...] you are always retracing your steps and asking yourself: did I do it right?", "I think about it even when I'm back home"). This reflection is the process that leads the professional to progress in their work and to build an individual way of knowing, helping to determine future attitudes, comprehend future problems and discover solutions ${ }^{(12)}$. By reflecting upon their experience, the professional is able to conform to the understanding of the problem or to devise a better or more general solution, and this is what characterizes learning in the nursing practice ("the next time you'll have more tranquility, more security"). Each new experience of reflection-in-action "enriches the repertoire" of the professional. "Reflection-in-action in a single case can be generalized to other cases," thus contributing "to the repertoire of exemplary professional themes, from which, in the subsequent cases, the professional may compose new variations" (own translation) ${ }^{(12)}$.

The uncertainty expressed in the discourses through propositions of reevaluation ("the difficulty that you are going through with the patient"), becomes a trigger for reflection-in-action, demonstrated by the pause in silence, and also for reflection on reflection-in-action, as evidenced by affirmation such as ("a single patient leads to this reflection for me, right? And for all the others, it makes me stop to think, am I doing it right, is this issue happening only with this one patient, or with everyone else too?"). In this sense, in the context of this study, the moment of uncertainty that provokes reflection-in-action triggers, in certain situations, a reflection on reflection-in-action that allows an evaluation and reproduction of the professional's activities as a whole, and not only on a case-by-case basis.

Reflection-in-action and reflection on reflection-in-action are noticeable features of the nurses' discourse, indicating that during and even after the nurse's work, the search for solutions able to improve the patient's conditions is common. Through reflection, the nurse seeks different ways to care, which leads to learning during practice and through practice. In this process, the nurse experiences the transformation of her way of being and acting. In the face of the above, reflection-in-action and the subsequent reflection on reflection-in-action enable the professional to transform knowledge-as-thought and knowledge-asdoing, because the daily action of reflection provides a constant dialogue between theory and practice ${ }^{(12)}$. 
In the work dynamics of nurses, the elements of a reflexive practice are revealed: knowing-in-action, reflection-in-action, and reflection on reflection-in-action. Thus, knowing-in-action manifests itself when they are in situations that are familiar to them, activating knowledge acquired through training and experience, and reproducing the social practice of nursing. However, at certain moments, surprise, which stems from variation, appears in supervised actions or in actions that mobilize reflection-in-action and reflection on reflection-in-action. Reflection, on the other hand, provides nurses with learning in $\mathrm{HC}$ by leading to a search for solutions to problematic situations, allowing the elaboration of new ways of acting. In this way, recognition and appreciation of the work of nurses in $\mathrm{HC}$, in its possibility of inducing the production of new care technologies, becomes fundamental.

\section{Limitations of this study}

Among the limitations of this study, the participation of only 13 nurses stands out. This does not, however, invalidate the results of this research, but rather indicates the need for further studies on the subject. Therefore, we consider it relevant for future research to put the practice of the nurse in $\mathrm{HC}$ into evidence, since it results from unforeseeable situations and solutions that are thought of and tested in action, in a reflexive process.

\section{Contributions to the area of nursing, health or public policy}

Considering the results of this study, we hope that it may contribute to the strengthening of good home care practices as a central focus of nursing, and for future research in this area, including new approaches. In addition, we speculate that these findings could be used by nurses working in $\mathrm{HC}$, provoking reflection on possible improvements in their professional practice, thus contributing to the provision of care consistent with the population's health needs and the structuring of health policies. The results indicate that the workplace should be considered as a space that provides reflection and learning through reflexivity, and points to the need to value the complex and particular aspects of home care in the training of nurses. Thus, the singular approach to home care should receive attention already in the nursing graduation phase.

\section{FINAL CONSIDERATIONS}

The discourses allowed the identification of actions and knowledge mobilized by the reflexive practice of the home care nurse. In their work dynamics, the elements of a reflexive practice emerge: knowing-in-action, reflection-in-action and reflection on the reflection-in-action. The results indicate that nurses act spontaneously in situations that are familiar to them and, to this end, mobilize knowledge established through academic training. At certain times, the unpredictability of the results of their actions mobilize reflexivity, which provides learning.

In practices complemented by reflection-in-action, nurses perform experiments in search of solutions to provide the best care to users and the best guidance to caregivers. This dynamic provides nurses with an opportunity for continuous learning. In this learning process, the nurse evaluates the problematic situation, creates or adapts solutions, implements and evaluates the effect, thus being able to reproduce it in other, similar situations. Our analysis indicates that reflection accompanies the actions of home care nurses, taking into account the fact that reflexivity in this work has an intentionality. As such, the search for improvement in patients' conditions directs nurses' actions.

In the reflexive process, the nurse idealizes actions to solve problematic situations, uncovers unpleasant surprises and creates corrections and experiments in the search for solutions. These attempts are not randomly interconnected. The reflection on each attempt and its results creates conditions for the subsequent action. In this way, it is possible to evidence the learning of solutions through reflexive practice, which provides for the reproduction of the action in later situations.

It should be noted that the methodological approach adopted was adequate to achieve this study's objective. Observation of the nurses' work was an important factor for the production of the data, evidencing the reflection that takes place during the nurses' practice.

\section{FUNDING}

We thank the Postgraduate Collegiate of the Nursing Course of the Federal University of Minas Gerais (PRPq/UFMG) for the financial support received.

\section{REFERENCES}

1. Gonçalves JRL, Gonçalves AR, Silva KR, Contim D. Home care services in Brazil: a bibliographic review. REFACS (online) [Internet]. 2017 [cited 2018 Mar 12];5(3-Esp):440-9. Available from: http://dx.doi.org/10.18554/refacs.v5i3.2046

2. Silva KL, Silva YC, Lage ÉG, Paiva PA, Dias OV. Why is it better at home? service users' and caregivers' perception of home care. Cogitare Enferm [Internet]. 2017 [cited 2018 Feb 24];(22)4:e49660. Available from: http://dx.doi.org/10.5380/ce.v22i4.49660

3. Andrade AM, Silva KL, Seixas CT, Braga PP. Nursing practice in home care: an integrative literature review. Rev Bras Enferm [Internet]. 2017 [cited 2018 Feb 15];70(1):199-208. Available from: http://dx.doi.org/10.1590/0034-7167-2016-0214

4. Silva KL, Sena RR, Silva PM, Braga PP, Souza CG. Supplementary home health care services and the inclusion of nursing in Belo Horizonte/ Minas Gerais (Brazil). Acta Paul Enferm [Internet]. 2012 [cited 2018 Feb 15];25(3):408-14. Available from: http://dx.doi.org/10.1590/ S0103-21002012000300014

5. Stajduhar KI, Funk L, Roberts D, McLeod B, Cloutier-Fisher D, Wilkinson C, et al. Home care nurses' decisions about the need for and amount of service at the end of life. J Adv Nurs [Internet]. 2011 [cited 2018 Oct 20];67(2):276-86. Available from: http://dx.doi. org/10.1111/j.1365-2648.2010.05491.x 
6. Furåker C. Registered nurses' views on competencies in home care. HHCMP [Internet]. 2012 [cited 2018 Oct 20];24(5):221-7. Available from: https://doi.org/10.1177/1084822312439579

7. Castro EAB, Leone DRR, Santos CM, Neta FCCG, Gonçalves JRL, Contim D, et al. Home care organization with the Better at Home Program. Rev Gaúcha Enferm [Internet]. 2018 [cited 2018 May 25];39:e2016-0002. Available from: http://dx.doi. org/10.1590/1983-1447.2018.2016-0002

8. Hermann AP, Lacerda MR, Nascimento JD, Gomes IM, Zatoni DCP. Enhancing the process of teaching and learning homecare. Rev Bras Enferm [Internet]. 2018 [cited 2017 Dec 28];71(1):156-62. Available from: http://dx.doi.org/10.1590/0034-7167-2016-0541

9. Cunha JJ, Lepinski AG, Santos MS, Hermann AP, Bernardino E, Lacerda MR. Nursing's contributions to improvements in home healthcare management. J Nurs UFPE Online [Internet]. 2015 [cited 2017 Apr 17];9(5):7746-52. Available from: http://dx.doi.org/10.5205/ reuol.6121-57155-1-ED.0905201501

10. Hermann AP, Lacerda MR, Maftum MA, Bernardino E, Mello ALSF. The home care teaching and learning process in undergraduate health care degree courses. Ciênc Saúde Colet [Internet]. 2017 [cited 2018 Apr 2];22(7):2383-92. Available from: http://dx.doi. org/10.1590/1413-81232017227.23672015

11. Andrade AM. Aprendizagem reflexiva de enfermeiras na atenção domiciliar: caminhos para uma práxis criadora [Thesis].[Internet]. Belo Horizonte: Universidade Federal de Minas Gerais; 2017 [cited 2019 Mar 17]. 207 p. Available from: http://hdl.handle.net/1843/ ANDO-ARSQZR

12. Schön DA. Educando o profissional reflexivo: um novo design para o ensino e a aprendizagem. Porto Alegre (RS): Artmed; 2000.

13. Ministério da Saúde (BR). Resolução CNS/MS no 466, de 12 de dezembro de 2012 [Internet]. Diário Oficial da União: República Federativa do Brasil; 2013. Jun 13 [cited 2018 Oct 20];1:59. Available from: http://conselho.saude.gov.br/resolucoes/2012/Reso466.pdf

14. Yin RK. Estudo de caso: planejamento e métodos. 4th ed. Porto Alegre (RS): Bookman; 2015.

15. Andrade SR, Ruoff AB, Piccoli T, Schmitt MD, Ferreira A, Xavier ACA. Case study as a nursing research method: an integrative review. Texto Contexto Enferm [Internet]. 2017 [cited 2017 Nov 2];26(4):e5360016. Available from: http://dx.doi.org/10.1590/0104-07072017005360016

16. Minayo MCS. O desafio do conhecimento: pesquisa qualitativa em saúde. 13th ed. São Paulo (SP): Hucitec; 2013.

17. Lapassade GL. L'observation participante. Rev Eur Etnog Educ. 2001;1:9-26.

18. Kock IV. A interação pela linguagem. São Paulo (SP): Contexto; 1997.

19. Fairclough N. Discurso e mudança social. 2nd ed. Brasília (DF): Universidade de Brasília; 2001.

20. Godoy AS. Refletindo sobre critérios de qualidade da pesquisa qualitativa. Rev Eletr Gestão Organizacional [Internet]. 2005 [cited 2018 Oct 20];3(2):80-9. Available from: https://periodicos.ufpe.br/revistas/gestaoorg/article/view/21573/18267

21. Fairclough N. Discurso e mudança social. Brasília (DF): UNB; 2008.

22. Tong A, Sainsbury P, Craig J. Consolidated criteria for reporting qualitative research (COREQ): a 32-item checklist for interviews and focus groups. Int J Qual Health Care [Internet]. 2007 [cited 2018 Oct 20];19(6):349-57. Available from: http://dx.doi.org/10.1093/intqhc/mzm042

23. Arendt H. A vida do espírito. 2nd ed. Rio de Janeiro (RJ): Civilização Brasileira; 2010.

24. Andrade FR. [Narrative and understanding in the educational writings of Hannah Arendt]. Educ Rev [Internet]. 2013 [cited 2017 Jan 17];29(4):37-68. Available from: http://dx.doi.org/10.1590/S0102-46982013005000005 Portuguese.

25. Guerra EO. Um tratado de paz entre o pensar e o querer: a sugestão de Hannah Arendt. Peri [Internet]. 2014;6(1):158-71. Available from: http://www.nexos.ufsc.br/index.php/peri/article/viewFile/913/416

26. Andrade AM, Silva KL. Adaptations and inventions in the praxis of nurses in home care: implications of the reflective practice. Esc Anna Nery [Internet]. 2018 [cited 2018 Oct 20];22(3):e20170436. Available from: http://dx.doi.org/10.1590/2177-9465-EAN-2017-0436 